Témoigner Témoigner. Entre histoire et mémoire

Getuigen Revue pluridisciplinaire de la Fondation Auschwitz

118 | 2014

Au nom des victimes. Dictature et terreur d'État en Argentine, Chili et Uruguay

\title{
Slachtoffers, families en burgers. De strijd om het legitieme verhaal
}

Familles et victimes. Quelle place pour les citoyens?

Relatives and victims. What is the role of the citizens?

\section{Elizabeth Jelin}

Traducteur : Antonia García Castro

\section{(2) OpenEdition}

Journals

\section{Édition électronique}

URL : http://journals.openedition.org/temoigner/1100

DOI : 10.4000/temoigner. 1100

ISSN : 2506-6390

Éditeur :

Éditions du Centre d'études et de documentation Mémoire d'Auschwitz, Éditions Kimé

Édition imprimée

Date de publication : 1 octobre 2014

Pagination : 88-97

ISBN : 978-2-84174-674-3

ISSN : 2031-4183

Référence électronique

Elizabeth Jelin, «Slachtoffers, families en burgers. De strijd om het legitieme verhaal », Témoigner. Entre histoire et mémoire [Online], 118 | 2014, Online op 01 octobre 2015, geraadpleegd op 23 octobre 2020. URL : http://journals.openedition.org/temoigner/1100 ; DOI : https://doi.org/10.4000/ temoigner. 1100 


\section{ARGENTINIË}

\section{Slachtoffers, families en burgers}

De strijd om het legitieme verhaal'

$\rightarrow$ Elizabeth Jelin,

Buenos Aires

(1) Dit is een herziene en verkorte versie van de tekst: ¿Victimas,
familiares o ciudadanos/as? Las luchas por la legitimidad de la
palabra', in Emilio Crenzel (red.), palabra', in Emilio Crenzel (red).
Los desaparecilos en la Argentina. Memorias, representaciones
eideas (1983-2008), Buenos Aires: Editorial Biblos, 2010
lk dank Richard A. Wilson en mijn collegás van de Núcleo de Estudios sobre Memoria van he
IDES voor hun suggesties en
apmerkingen. Een uitgebreide versie werd in het Engels gepubliceerd: 'Victims, Relatives,
and Citizens in Argentina: Whose Voice Is Legitimate Enough??, in

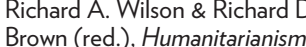
and Suffering: The Mobilization of Empathy, Cambridge: Cambrid et herinneringswerk in Argentinië, en met name de discussie over het leverledenvandejrenzeventio wordtbeheerstdoorpersoonlijke lijdensverhalen en de status van 'rechtstreeks getroffen personen' De naasten van de slachtoffers, en in tweede instantie de overlevenden, hebben een aanzienlijke invloed in de publieke ruimte en bepalen de richting van de debatten over de schending van mensenrechten in die periode. Wat 'war' en legitiem is, wordt gedicteerd door de persoonlijke ervaringen de genetische band Het familisme en de vitdrukkelijke verwijzing nar het militantisme van de rheersen alle andere maatschappeljke stemmen. In het publiek debat over de interpretatie van het verleden en het beleid daarrond, is op die manier geen ruimte voor een bredere humanistische kijk op de feiten.

Kan het dan anders? Is er in Argentinië plaats voor een universalistische visie op de schending van mensenrechten tijdens de dictatuur? Vormt de autoriteit van de getuigen met hun persoonlijke verhalen hierin een hinderpaal? Dat hoeft in principe niet zo te zijn, maar verhalen over verloren familieleden en fysiek lijden onder de repressie zijn nu eenmaal alomtegenwoordig in Argentinië, en genieten een zekere legitimiteit. Ze hebben zo een politiek kader geschapen waarbinnen de begrippen 'setroffen persoon'en 'burger' elkar uitsluiten, en het eerste het tweede gaat overschaduwen.

\section{DE PLAATS VAN DE FAMILIE IN HET HERINNERINGSBELEID}

Al ten tijde van de Argentijnse staatsrepressie, onder de dictatuur van 1976-1983 stond de familie centraal. De militaire regering die in maart 1976 aantrad beschouwde zichzelf als redder van de natie. Ze trok ten strijde tegen de chaos en tegen subversieve factoren die de 'natuurlijke' waarden en instellingen van de Argentijnse aard ondermijnden. Om die waarden veilig te stellen moesten staat, familie en burgers beschermd worden tegen de gevaren van zulke subversieve activiteiten.

De traditionele familievormde het middelpunt van het dictatoriale wereldbeeld. Het was de enige manier - de enige 'natuurlijke' manier - om de samenleving te organiseren. Dat idee lagaan de basis van een grootschaligecampgne die het taire regime lanceerde ter bescherming van de familie. Bovendien werd de fami-

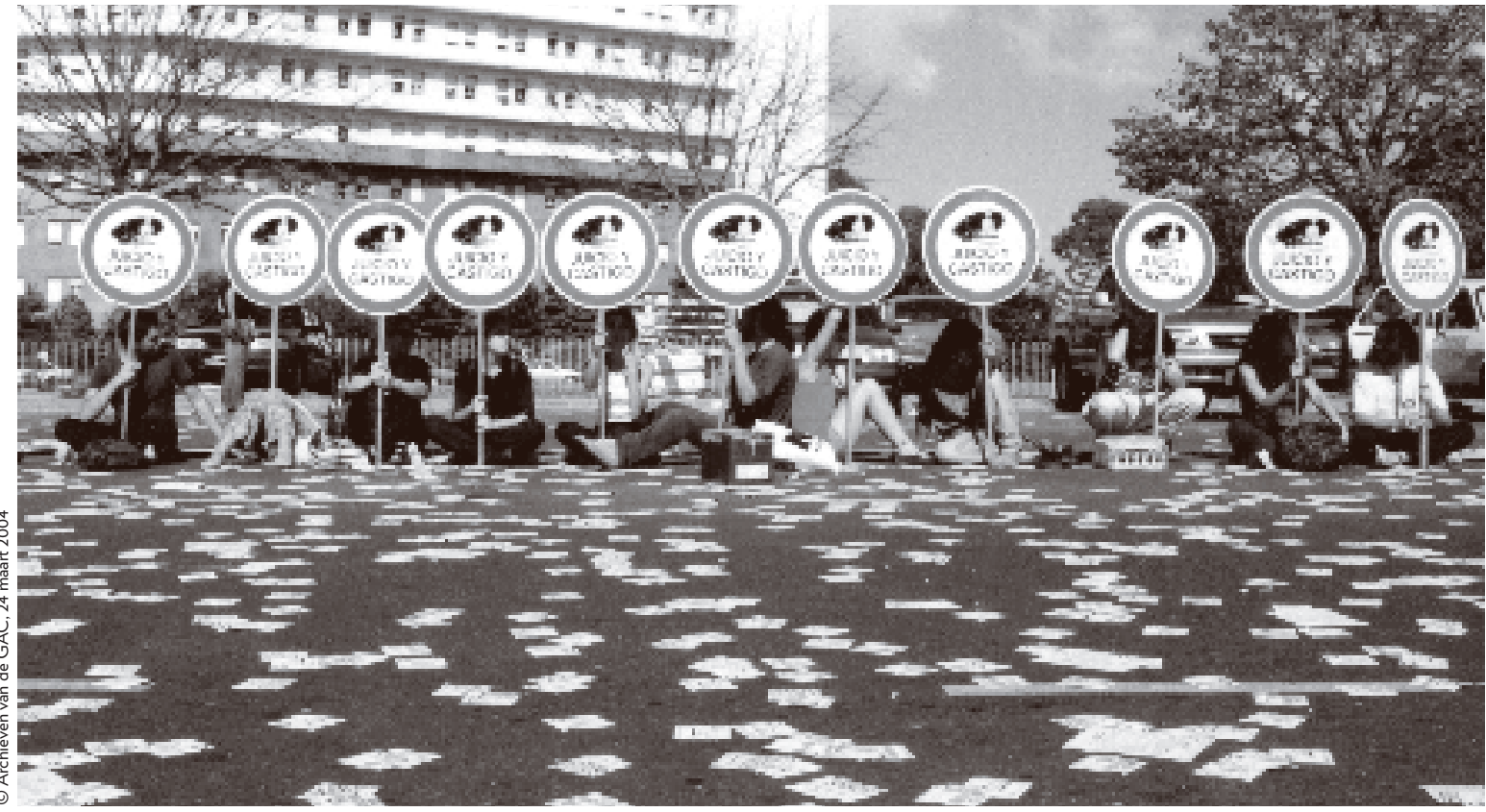

liale metafoor ook gebruikt om naar de natie als geheel te verwijzen en verwier Vader-Staat onvervreemdbare rechten op het doen en laten van de burgers. In dit discours draaide alles om vaderlijke autoriteit: van de kinderen werd verwacht dat zij gehoorzaamden. Er was geen plaats voor burgers met eigen rechten, voor mensen met een autonome wil.

Die nieuwe wereld kende geen maatschappelijke of culturele basis, maar een 'natuurlijke' Het gevaar, dat werd belichaamd door het kwaad of de ziekte, kwam ' 'na buitenaf - het was een vreemd licham dat de eigen wereld binnendrong en het natuurlijke evenwicht te he nodig: de besmette sociale weefsels moesten worden woggentigd. Het militaire regime nam daarom de zware taak op zich van de vader die zijn familie moet zuiveren en beschermen, en kreeg daarbij de hulp van 'secundaire' vaderfiguren die de rebelse adolescenten controleerden en disciplineerden. De overheid wist haar greep op het privéleven van gezinnen in die mate te vergroten, dat uiteindelijk elk onderscheid tussen openbaar en privéleven vervaagde.

In 1976 kwamen de families van verdwenen gevangenen bijeen en richtten de organisatie Familiares de Desaparecidos y Detenidos por Razones Políticas op (Familieleden van verdwenen en opgesloten personen om politieke redenen). In worden van de
-Herdenking van 24 maart
in de ESMA, betogingen van Grupo de Arte Callejero 
Plaza de Mayo. H.I.J.O.S. (Spaans acroniem voor 'Kinderen van verdwenen personen voor identiteit en rechtvaardigheid, tegen vergeten en zwijgen) komt er twintig jaar later, en Herman@s in de loop van de 21ste eeuw. Tot op de dag van vandaag blijven al deze verenigingen hun vraag herhalen naar rechtvaardigheid, waarheid en herinnering. Opvallend genoeg belichamen de organisaties geen metaforische of symbolische familieband, maar mobiliseren ze tijdens publieke acties de letterlijke (en biologische) betekenis ervan.

Waarom spelen de mensenrechtenbewegingen die familieband telkens uit? Men mot weten at tijdens de periode van dictatur, represse enc centur, politio moet weten dat tijden de periode van dictatuur, repressie en censuur, politieke organisaties en vakbonden verboden waren. Net zoals het dictatoriale regime in haa discours de familie opvoerde als 'natuurlijk' element van de maatschappelijke orde zo grijpt ook een heel aantal 'mensenrechtenorganisaties' terug naar dat concept. De enige protesten die het dictatoriale regime toestond, waren die van de families. Tenslotte waren dat gewoon moeders die hun kinderen zochten...

Dat is meteen ook de grote paradox van het Argentijnse regime tussen 1976 en 1983: het beeld van de familie vormde de centrale metafoor in het militaire verhaal, maar ook in het discours en de praktijk van de mensenrechtenbeweging. ${ }^{2}$

Het is opvallend dat familiebanden zo centraal staan in de publieke en politieke strijd. Die strategie heft natuurlijk haar specifieke doeleinden mar impliceert strijd. Die stratejer een nieuwe inviling van deviveven. De 'mensenrechtenbeweging houdt de samenleving voor dat de band tussen familie en slachtoffer de legitieme basis vormt van haar acties. Voor de rechterlijke macht i dat in feite de enige basis: enkel overlevenden en naaste familieleden worden immer beschouwd als 'getroffenen' en hebben recht op een persoonlijke en individuele vergoeding. Het fenomeen van familisme in het publieke domein heeft echter een culturele en politieke impact die we niet kunnen ontkennen. De Moeders hebben hun moederschap uitvergroot door te claimen dat alle verdwenen personen zonen en dochters zijn van alle moeders. Tijdens publieke manifestaties creëren zij zo tegelijkertijd een onoverbrugbare afstand tussen henzelf en alle andere mensen die voor dezelfde zak strijden mar en kunnen gewicht in de schaal leggen wanneer de familieband met het slachtoffer motieven volstaan niet, tenzij 'rechtstreeks getroffen' personen de eisen 'kracht bijzetten'

\section{VAN SLACHTOFFR TOT RECHTSPERSOON.}

WAARHEID EN RECHTVAARDIGHEID IN DE OVERGANGSPERIODE

De nadruk op het familisme is slechts een deel van het verhaal. Met het einde van de dictatuur en de invoering van een grondwettelijk bewind in december 1983 ontstond ook de vraag naar een institutionele aanpak van de schending van de menhander de verdwijning van personen), die getuigenissen moest verzamelen bij familieleden van vermiste personen en overlevenden uit de gevangenkampen. ${ }^{3}$

Een jaar later, in 1985, kondigde het roemruchte proces tegen de voormalige commandanten van de militaire junta een nieuwe fase aan in de strijd voor mensenrechten in Argentinië. Het institutionele middelpunt werd gevormd door de rechterlijke macht, haar procedures, formaliteiten en rituelen - de slachtoffers waren nu 'getuigen' en de leden van de repressie 'beschuldigden'; de politieke actoren fungeerden als 'waarnemers' van de rechterlijke beslissingen, terwijl de rechters optraden als neutrale autoriteiter

Het proces kan historisch genoemd worden en vormde een overwinning voor de rechtsstaat. Het slachtoffer werd een volwaardig rechtspersoon, en ging het nieuwe democratische regime belichamen. Toch betekende dit nog niet het einde van het lijden en de afrekeningen; meer dan ooit tevoren zouden persoonlijke en familiale banden weer gaan doorwegen

Het werk van de CONADEP, en vooral de processen, vormden werkelijk een keerpunt voor de slachtoffers. Op het moment dat iemand verdwijnt, gemarteld en clandestien gevangengenomen wordt, is de maatschappelijke en politieke band tussen die persoon en de beul opgeheven ${ }^{5}$ De rechtstreekse relatie die dan nog tussen hen besta t valt buiten elk matschappelijk f politiek kader. Het sho hof spreekt ons toe vanuit een wereld die voor ons niet bestaat. Het lijkt wel alsof die stem er nooit is geweest, omdat binnen een context van willekeurige terreur en totalitaire macht niemand het verhaal kan natrekken. De slachtoffers zijn bijgevolg veroordeeld tot zwijgen, of worden niet geloofd. De positie van de rechtspersoon is dan wel heel anders: beide partijen in het conflict hebben in dat geval toegang tot een hogere autoriteit, een rechtbank die de waarheid kan vastleggen volgens bepaalde regels en procedures van bewijsvoering. Vanaf het moment dat de wet tussenkomt, verandert de positie van de betrokken partijen radicaal: beide worden erkend als betrokkene in het conflict.

Hetbelang van het proces en de uitspraak (in december 1985) kan moeilijk onderschat worden, omdat het om veel meer draaide dan de veroordeling van de voormalige commandanten. Niet alleen werd het systematische karakter van de militaire repressie aangetoond; dankzij de gegevens die tijdens het proces werden verzameld, kon een corpus worden aangelegd dat ook voor andere processen bruikbaar was. Overigens is het verhaal niet ten einde met het proces. Militaire protesten en opstanden hebben namelijk voor een institutionele ommekeer gezorgd. Om nieuwe rechtszaken zoveel mogelijk te vermijden, verwees men telkens weer naar de conclusies uit 1985. Het leek niet meer nodig om de rol van de rechtsstaat te bekrachtigen of de wettelijke rechten van de slachtoffers te vrijwaren. Op het moment dat de staat zich terugtrok uit het proces van institutionele hervorming, kwam het initiatief weer bij de matschappelijke actoren te ligien, en in het bijzonder bij de stachtoffers en hun familieleden. De Moeders van de Plaza de Mayo zetten hun acties voort en hun familieleden. De net als de Grootmoeders die streden tegen de ontvoering van minderjarigen en de
illegale adoptie.
(3) Voor een uitgebreidere analyse vervijzen we naar Carlos
H. Acuña \& Catalina Smulovitz Militares en la transición argentina: del gobierno a la
subordinación constitucional', in Carlos H. Acuña e.a., op. cit, 19-99; Emilio Crenzel, La historia pera de lo CAMAS. La Argentiana, Buenos Aires: Siglo
XXI Editor,

(4) Tijdens het proces werden
generaal Jorge R. Videla en admiraal Emilio Masser tot levenslange opsluiting
veroordeeld. Generaal Robert Viola ging 17 jaar achter de tralies
admiraal Armando Lambshini 8 jaar en brigadier Agosti 3 jaar en 9 maanden. Wegens gebrel de Federale Kamer de zaken tegen de leden van de laatste militaire junta (1979-1983): en braigadiers Lami Dozo en
Lay Graffigna. (5) Inés González Bombal,
Nunca Más. El juicio más allá de los.a., op cit., 193-216. 
DE ZOEKTOCHT VAN DE GROOTMOEDERS, DE DNA-TESTEN EN DE IDENTITEIT VAN DE KINDEREN

Het militaire bewind heeft duizenden mensen ontvoerd en doen verdwijnen. Minderjarige kinderen werden samen met hun ouders weggehaald, maar ook jonge zwangere vrouwen werden slachtoffer. Het is rond deze gebeurtenissen dat de Grootmoeders van de Plaza de Mayo actie voeren ${ }^{6}$

Toen bleek dat niet alle kinderen waren vermoord maar dat zij in vele gevallen een andere identiteit hadden gekregen, zetten de Grootmoeders allerhande initiatieven op. De wetenschap had hiervoor nieuwe technieken ontwikkeld. omdat de biologische ouders van de kinderen vermist waren, werden genetische stalen en bloedstalen genomen van de tweede en derde generatie (grootouders, ooms en tantes). In 1992 ontstond de Nationale commissie voor het recht op identiteit (CONADI), die een Nationale bank van genetische informatie oprichtte.

Het initiatief om de vermiste kinderen hun identiteit terug te schenken heeft - Betoging op de Plaza van de Plaza de Mayo met zwarte figuren die de verdwenen gevangene moeten voorstellen Grootmoeders kunnen duidelijk op matschappelijke steun en bewondering rekenen op maatschappelijke steut initiatief rond de identificatie van kinderen die zijn ontvoerd of geboren in gevangenschap. Aangezien de genetische databank en de DNA-testen onontbeerlijk zijn om deze opdracht tot een goed einde te brengen, wordt de indruk gewekt dat de uiteindelijke waarheid te vinden is in genetica, biologie en bloedstalen.

Toch is er een contradictie ontstaan die grote maatschappelijke gevolgen zou kunnen hebben. Nu we op een moment in de geschiedenis zijn aanbeland waarin genetica een belangrijke rol speelt in gezinsproblematieken, wordt ook in de Argentijnse context gebruik gemakt van genetisch bewijsmaterial. Familiebangen zijn echter in den tureel bepaald. Hoe verzoenen gerechtelijke systemen en maatschappijen deze twee normatieve kaders? De Argentijnse maatschappij - en zelfs onze hele maatschappij - zal een normatief antwoord moeten formuleren op een hele reeks vragen: zo zijn er de ethische dilemma's rond nieuwe voortplantingstechnieken, de regels rond adoptie en het recht van kinderen om hun afkomst te kennen (opgenomen in de Internationale conventie voor de rechten van het kind), en de medische vooruitgang rond de diagnostisering van genetische afwijkingen Gezien de culturele en politieke beteken van de identiteitszoektocht die er sinds 35 jaar wordt

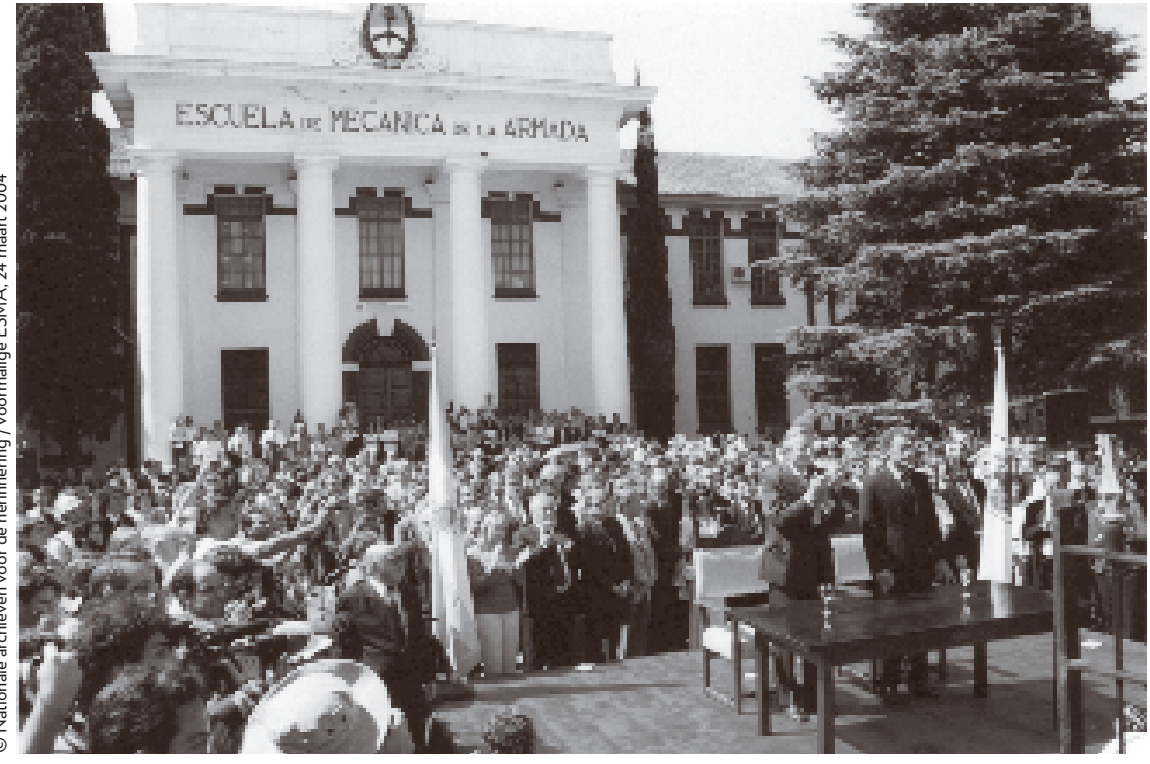

- Herdenking van 24 maart 2004 in de voormalise tekenen president Néstor Kirchner en burgemeester
van Buenos Aires Aníbal tbarra het akkoord waarbij aan de stad.

gevoerd, en het belang van genetische testen om de 'waarheid' bloot te leggen, vorm Argentinië een perfecte casus om na te gaan hoe doorslaggevend biologische en culturele elementen zijn om familierelaties te definiëren.

\section{SPOTS OP DE OVERLEVENDEN TIJDENS} HERDENKINGSPLECHTIGHEDEN

Jaarlijks wordt in Argentinië op 24 maart de staatsgreep van 1976 herdacht. De datum heeft een verschillende beteke en . ging" de publieke ruimte op en organiseert diverse activiteiten om het dictatoriale
tijdperk te herdenken. tijdperk te herdenken.

De plechtigheid van 24 maart 2004 was opmerkelijk. De nieuwe president Néstor Kirchner en de burgemeester van Buenos Aires, Aníbal Ibarra, ondertekenden een akkoord om een herdenkingsplek te maken van de Marine Werktuigkundigenschool (ESMA), waar indertijd een 5000-tal mensen gevangen werd gehouden en de meerderheid vermist raakte.

Hoewel de overlevenden al eerder getuigden, is hun publieke optreden nooit evident geweest. Het feit dat ze de verschrikkingen hadden overleefd, wekte namelijk argwaan op bij veel mensen en heeft de receptie van hun verhalen bënvloed. Niemand twijfelde eran dat ze veel hadden doorstan hun relas over de leved. er de levensmen verdacht vond, waren niet de verhalen maar de stiltes (hebben ze misschien

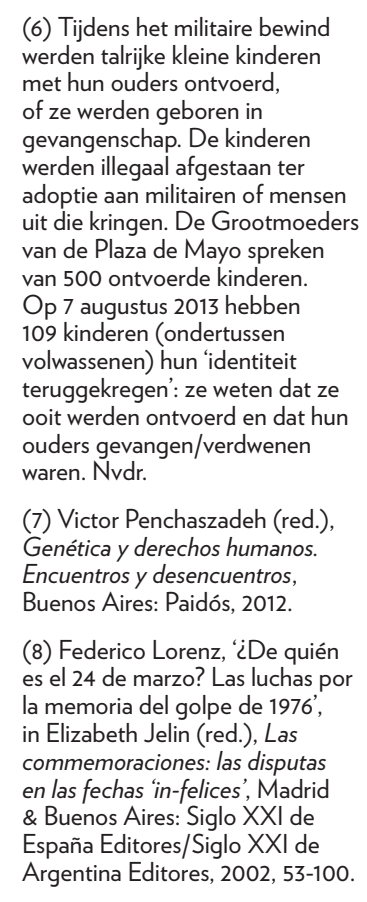


(9) Pilar Calveiro, Podery
desaparición Los campos concentración en Argentina,
Buenos Aires: Colihue, 1998. (10) Ana Longoni, 'Traiciones. La
figura del traidor (y la traidora) en los relatos acerca de los
sobrevivientes de la represión', in
Elizabeth Jelin \& Ana Longoni Elizabeth Jelin \& Ana Longo
(red.), Escrituras imágenes, (red.), Escrituras, imágenes,
escenarios ante la represión, XXI de España Editores/Siglo XXI de

(11) Het Peronisme is een Argentinnse politieke beweging figuur van Juan Domingo Perón
politiek leider en president van de Argentijnse republiek tussen 1946 en 1955 en tussen 1973 en

gecollaboreerd? anderen verklikt of verraden?). Volgens Pilar Calveiro ${ }^{9}$ is het echter een illusie te denken dat de gevangenen hun eigen lot konden beïnvloeden: de macht was totaal en willekeurig, en lag volledig in handen van de beulen. Niets van wat de slachtoffers deden of zeiden kon iets an hun situatie veranderen. Desondanks duikt het motief van verraad of verklikking vaak op in rapporten uit die tijd, en zelfs in fictie..$^{10}$

De herdenking van 24 maart 2004 is daarom opmerkelijk. De overlevenden van de ESMA stonden ditmaal in de schijnwerpers: ze verkenden de plek en toonden waar ze werden vastgehouden, gemarteld en opgesloten.

Tijdens de plechtigheid vertelden de aanwezigen elk een bijzonder en persoonlijk verhaal over de plaats. Zo werd een gedicht voorgelezen dat was geschreven door een vriend van de president, een voormalig gevangene in de ESMA van wie men nooit meer iets heeft gehoord. De burgemeester vertelde dan weer over zijn studievriend die is verdwenen in de ESMA, en de aanwezige jongeren deelden hun ervaringen over het leven na de geboorte in de gevangenis.

De president richtte zich uitdrukkelijk tot een specifiek publiek, namelijk de naasten van de verdwenen personen - moeders, grootmoeders, zonen en dochters. Het was duidelijk dat de families moesten getuigen in de plaats van de afwezigen. In zijn toepraak profleerdedepresident zich als lid vaneen welbepaaldeplitieke epaalde politieke groepering, maar vooral ook als lid van eengeneratie nilitanten die hadden gestre(ajn toevallig refereerde hij vaak aan zijn 'kameraden'. Hij richtte zich op geen enkel moment tot de hele samenleving, tot de burgers van het land. Zijn enige toehoorders leken de slachtoffers en hun families, en zijn 'kameraden'

Het is bijzonder dat tijdens de herdenking en de toespraken erg nadrukkelijk de banden werden aangehaald tussen voormalige militanten en politieke activisten van de jaren zeventig, de linkse Peronisten. ${ }^{11}$ We mogen echter niet vergeten dat de politieke repressie en het militaire regime ook andere slachtoffers heeft gemaakt - linkse revolutionairen bijvoorbeeld, die voornamelijk vervolod werden door de - link de ESMA. Toch stonden lokale belangen en verhalen voorop tijdens deze plechtigheid. Familiebanden en persoonlijke getuigenissen gingen opnieuw een wezenlijke plaats innemen in het herinneringsdiscours.

\section{SLACHTOFFERS EN FAMILIES, TOEN EN NU: WAT IS DE ROL VAN DE BURGER?}

Waar komt dat familisme dan vandaan? Wat is de politieke betekenis ervan? Om de wortels te vinden van het geheel van waarden en overtuigingen dat familisme wordt genoemd, moeten we diep graven in de culturele en politieke geschiedenis van het land. Sinds de koloniale periode heeft de Katholieke Kerk een belangrijke culturele rol gespeeld in Argentinië en andere Latijns-Amerikanse lon Ink (n) In dat katholieke discours, dat zich ent op de sterke culturele traditie van het 'Marianisme'
(waarbij de moeder, belichaamd door de Maagd Maria, de belangrijkste referentie

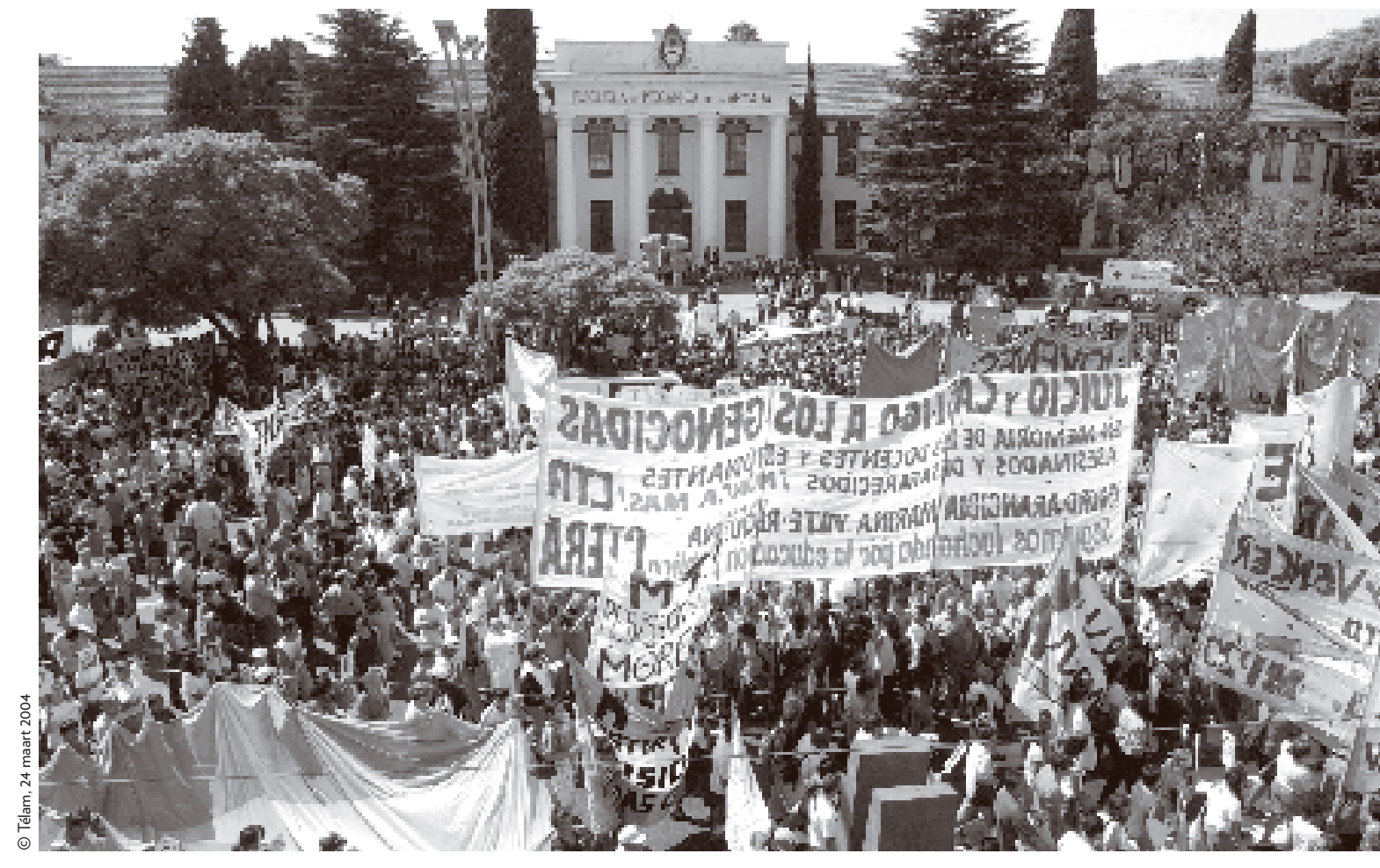

is), vormt de 'natuurlijke' familie de 'kern' van de maatschappij. Dit discours is van grote invloed geweest op het beleid in Argentinië en op de manier waarop de staat de verhouding tussen familie en publieke sfeer definieerde. Aan het eind van de negentiende, begin twintigste eeuw, importeerden Europese immigranten bovendien (a) als geïsoleerde individuen maar als leden van een uitgebreid netwerk van families en gemeenschappen, verbonden door solidariteit, wederzijdse banden en verantwoordelijkheden. Dat model is ook kenmerkend voor latere migratiestromen in andere Latijns-Amerikaanse landen. De ethiek van het familieleven is dus geworteld in een belangrijke historische traditie.

De basis van het familisme is een individuele en lokale invulling van interpersoonlijke en politieke verbondenheid. Het betreft in geen geval een abstracte en anonieme relatie, maar een persoonlijke relatie die een hiërarchische en patriarchaal-familiale band veronderstelt tussen twee mensen. Het familisme overstijgt soms de bloedband en krijot een publiek of politiek karakter In dat geval rathetom 'verticale' retatie waarijiemand persoonlijke beschemning Het is indezent gerschap te promoten, en daar is men uiteindelijk ook niet helemaal in geslaagd. De
- Herdenking van 24 maart, betogingen van de ESMA. 

tussen 'formele' democratie en rechtspraak enerzijds, en 'sociale' rechtvaardigheid gebaseerd op verdeling van rijkdom anderzijds. ${ }^{12}$ In Argentinië, zo kan men stellen, bestaat nog geen volwaardige cultuur gebaseerd op de institutionele en onpersoonlijke principes van wetten en rechten. Pogingen in die richting werden in de kiem gesmoord onder de dictatuur, toen burgerrechten onbestaande waren en de beulen over een absolute en willekeurige macht beschikten. Van een politieke gemeenschap als dusdanig was geen sprake meer; enkel familiebanden wisten deze perije doorstaan.

inergangsproces en het herstel van het legitieme staatsgezag, voornamelijk in de periode na het proces van 1985, kregen de slachtoffers weer een burgerlijke en politieke identiteit. In zekere zin was dit een performatief gebeuren waarbij zowel het burgerschap als de rechtsstaat werden hersteld. Het was in elk geval een sleutelmoment dat de basis zou vormen van verdere ontwikkelingen in de verhouding tussen burger en wet..$^{13}$

Historische processen zijn echter zelden lineair. Na het proces tegen de militaire junta trok de staat zich terug en verslapte de aandacht voor de juridische beslechting van het gewelddadige verleden. Omdat de zaak het maatschappelijke veld had weten te mobiliseren en de gemeenschap van 'rechtstre ks getroffen personen' te goed georganiseerd was, werd de publieke ruimte opnieuw door deze actoren ingenomen. De aandacht verschoof weer naar het persoonlijke lijden en de getuigenis. Het politieke en culturele landschap veranderde, en gaandeweggaf men de voorkeu aan verhalen die de rol van familie en overlevenden benadrukten (zoals dat van de president), in plaats van de feiten in een ruimer kader te plaatsen en zo de hele politieke gemeenschap te betrekken.

Uiteraard trekt niemand het lijden van de slachtoffers in twijfel, noch hun rech (of dat van de maatschappij) om meer te weten te komen over wat hen is overkomen tijdens de dictatuur. Het staat ook buiten kijf dat de rechtstreeks betrokkenen en hun families een cruciale rol hebben gespeeld in het protest tegen de repressie en de vrag nar waarheid en naar wij die het herije de 'wij' die het herije te maken tussen 'wij' - zij die tot de gemeenschap van de spreker behoren - en de 'anderen' - zij die luisteren of toekijken maar in feite aan de zijlijn blijven staan? Of nodigt die 'wij' de gesprekspartner precies uit om deel uit te maken van het verhaal? De twee interpretaties hebben altijd naast elkaar bestaan, en gaven aanleiding tot spanningen, misverstanden en onduidelijkheden. De vraag die we ons moeten stellen is daarom de volgende: beperkt de 'wij' in het herinneringswerk zich tot de groep van mensen die dat verleden persoonlijk hebben beleefd en sluit het de anderen uit, of kan de categorie ruim genoeg opgevat worden zodat ook gewone burgers kunnen deelnemen aan het debat?

Dan blijft de vraag of we op basis van herinnering en rechtspraak het debat kunnen verruimen. Moeten we ons beperken tot de gebeurtenissen waar we zonet over spraken, of wordt het tijd om ook andere verhalen onder de aandacht te brengen?
Men kan het verleden zien als iets unieks dat nergens anders mee te vergelijken valt en dat zich ook nooit meer zal herhalen. In dat geval beoogt het herinneringswerk veeleer een gedetailleerde beschrijving van de feiten, dan dat het een leidraad biedt voor beslissingen die we in de toekomst moeten nemen in andere domeinen van het leven. Zolang de klemtoon ligt op de absolute specificiteit van de persoonlijke herinnering, verengt het debat zich tot de gangbare thema's en verhalen.

Het is nochtans via de herinnering dat we een aantal vragen breder zouden kunnen formuleren, zonder af te doen an het unieke karakter van de ervaring. Wannen for neer we gan vergerinnering als voorbeld dienen Zo ontstaat de mogelijkheid om de pijn uit het verleden te verwerken, in plaats van haar het leven te laten overheersen. We kunnen lessen trekken uit het verleden en de stap zetten van privésfeer naar publieke ruimte, want ook binnen de rechtspraak en de instellingen speelt de herinnering een belangrijke rol. Uiteindelijk zullen herinnering en gerechtigheid gaan samenvallen en kan men de strijd aangaan met bewuste pogingen om het verleden uit te wissen. ${ }^{15}$

Zorgwekkend wordt het wanneer de autoriteit van de getuige en de waarheid de debatten gaan overheersen. Die waarheid dreigt op dit moment verankerd te worden in een essentialistisch-biologische kijk op de mens, die ons op en paradoxale den in een essentastisch-bios manier hilingonder het 'ijfelijke lijden, of het lijden van een bloedverwant of genetische verwant) gaat aan de basis liggen van ons idee van waarheid en legitimiteit: enkel aan mensen die lichamelijk lijden hebben ervaren, komt het maatschappelijke recht toe de herinnering te dragen. Vreemd genoeg vervalt die symbolische autoriteit al te makkelijk, bewust of onbewust, in een monopolie op zingeving en een eenzijdige invulling van de herinnering en de waarheid. De 'wij' in het verhaal wordt dan een factor van uitsluiting en kan niet op anderen overgedragen worden. In zijn meest extreme vorm belet deze situatie dat het maatschappelijk engagement rond de gedachtenis zich verbreedt: er is immers geen phats voor een herinterpretatie of eigen invulling van de ervaringen die ann anderen to behoren Het is dan ook een grote historische (a) demoging
(14) Tzvetan Todorov, Les abus de (15) Yosef $\mathrm{H}$. Yerushalmi, Refexiones Sobre el olvido, in
Yosef $H$. Yerushalmi e.e., Usos 